Beata Świecka

Marta Musiat

\title{
ENHANCING FINANCIAL LITERACY - EXPERIMENT RESULTS
}

\section{Abstract}

The goal of the paper is to assess whether a short course in financial education has a positive impact on subjective and objective assessments of financial knowledge. We present the results of a financial literacy experiment conducted at the University of Szczecin in 2016. The experiment was the outcome of international cooperation with Italian researchers, which allowed us to compare results obtained in Italy and in Poland. It was conducted with the methodology proposed by the Italian team. The experiment covered three topics: basic interest compounding, inflation and risk diversification.

Based on a sample of university students, we provide evidence that, in Poland too, a small-scale training intervention has both a statistically and economically significant effect on subjective assessments of financial knowledge and on objective assessments of investment attitudes.

Keywords: financial literacy, financial planning, financial education, investment attitudes.

JEL Classification: D14, G11, I20.

\section{Introduction}

The low level of household financial literacy raises doubts about the quality and rationality of the process of financial decision-making. Financial education is aimed at improving those decisions by helping consumers to acquire the knowledge and skills needed to understand the choices they face.

Beata Świecka, University of Szczecin, Faculty of Management and Economics Services, Department of Banking and Comparative Finance, Cukrowa 8, 71-004 Szczecin, Poland, e-mail: beata. swiecka@wzieu.pl

Marta Musiał, University of Szczecin, Faculty of Management and Economics Services, Department of Banking and Comparative Finance, Cukrowa 8, 71-004 Szczecin, Poland, e-mail: marta. musial@wzieu.pl 
The subject literature points to the importance of financial education in increasing knowledge and financial awareness, which is expected to translate into effectiveness in the field of financial decisions (Lusardi \& Mitchell 2014). Many studies of financial capability, financial literacy and financial education show that financial education has a positive impact on consumer behaviour and financial welfare. Lower levels of measured financial literacy are associated with lower rates of planning for retirement, lower rates of asset accumulation, lower participation in the stock market, higher rates of using alternative financial services and higher levels of debt (Ambuehl, Bernheim \& Lusardi 2014, Brown et al. 2014; Xiao \& O'Neill 2016). In order to examine the impact of financial education on financial knowledge, an experiment was carried out. It had previously been performed in Italy, and then was carried out in Poland using the same tools and methods.

The goal of this paper is to assess whether a short course in financial education has a positive impact on subjective and objective assessments of financial knowledge. The purpose of our study is to explore the potential effects of financial education on the financial literacy of young Polish consumers. We test the hypothesis that financial education is positively associated with financial capability. We present the results of a financial literacy experiment conducted in 2016. The experiment was the outcome of international cooperation with Italian researchers, which allowed us to compare results obtained in Italy and in Poland. The experiment covered three topics: basic interest compounding, inflation and risk diversification. Based on a sample of university students, we provide evidence that, in Poland too, a small-scale training intervention has both a statistically and economically significant effect on subjective and objective assessments of financial knowledge. The article describes financial knowledge and financial education, which are significant issues for European Union policy. Moreover, the article contains a international comparison of results.

\section{Financial Literacy and Related Terms - Conceptual Framework}

In order to achieve adequate transparency in the area of financial awareness it is essential to conceptually operationalise the main concepts and related terms. The broadest concept is financial capability, which is an important factor for the well-being of household members. Financial capability is the ability to apply appropriate financial knowledge and perform desirable financial behaviours to achieve financial goals and enhance financial well-being. Financial capability is a combination of 
financial literacy and financial behaviour whose purpose is to achieve financial wellbeing (Xiao 2016). According the National Financial Educators Council, financial literacy means "possessing the skills and knowledge on financial matters to confidently take effective action that best fulfils an individual's personal, family and global community goals" (NFEC 2014). The International Network on Financial Education has defined financial literacy as "a combination of awareness, knowledge, skill, attitude and behaviour necessary to make sound financial decisions and ultimately achieve individual financial wellbeing. OECD INFE members agreed that the various terms used to describe this concept (including in particular financial literacy and financial capability, but also financial culture and financial insight) could be used relatively interchangeably as they reflect similar perceptions of the reality they aim to cover. It was therefore decided to use the most common international term, financial literacy, for the purpose of this measurement survey" (INFE 2011). Financial literacy is knowledge of financial concepts and how the knowledge is used to make financial decisions, taking into account available resources and the unique situation of each individual or family (Delgadillo 2014). According to Xiao (2016), in addition to financial literacy, a second component that creates financial capability is financial behaviour, which should be understood to mean human behaviours relevant to money management. Financial behaviour often includes behaviours related to earning, spending, saving, and protecting (Xiao 2016).

The development of financial awareness is affected by financial education. The definition of financial education developed by the OECD in 2005 already identifies financial well-being as one of the main outcomes of the financial education process: "the process by which financial consumers/ investors improve their understanding of financial products, concepts and risks and, through information, instruction and/or objective advice, develop the skills and confidence to become more aware of financial risks and opportunities, to make informed choices, to know where to go for help, and to take other effective actions to improve their financial well-being" (OECD 2015). Financial education is believed to improve financial literacy, motivate desirable financial behaviours, and enhance financial well-being among consumers (Lusardi \& Mitchell 2014).

No single definition of financial literacy exists in the literature. It means different things for different people and organisations. Below we present some sample definitions. 
Table 1. Definition of Financial Literacy

\begin{tabular}{|c|c|}
\hline Organisation & Definition \\
\hline $\begin{array}{l}\text { Organisation } \\
\text { for Economic Cooperation } \\
\text { and Development }\end{array}$ & $\begin{array}{l}\text { A combination of awareness, knowledge, skill, attitude } \\
\text { and behaviour necessary to make sound financial decisions } \\
\text { and ultimately achieve individual financial well-being }\end{array}$ \\
\hline $\begin{array}{l}\text { Advisory Council } \\
\text { on Financial Literacy }\end{array}$ & $\begin{array}{l}\text { Personal financial literacy is the ability to use knowledge and } \\
\text { skills to manage financial resources effectively for a lifetime } \\
\text { of financial well-being. Personal financial literacy is more } \\
\text { than just being able to balance a checkbook, compare prices } \\
\text { or get a job. It also includes skills like long-term vision and } \\
\text { planning for the future, and the discipline to use those skills } \\
\text { every day }\end{array}$ \\
\hline $\begin{array}{l}\text { United States Government } \\
\text { Accountability Office }\end{array}$ & $\begin{array}{l}\text { Financial literacy, sometimes referred to as financial } \\
\text { capability, has been defined as the ability to use knowledge } \\
\text { and skills to manage financial resources effectively for } \\
\text { a lifetime of financial well-being. Financial literacy } \\
\text { encompasses financial education - the process by which } \\
\text { individuals improve their knowledge and understanding of } \\
\text { financial products, services, and concepts. However, to make } \\
\text { sound financial decisions, individuals need to be equipped } \\
\text { not only with a basic level of financial knowledge, but also } \\
\text { with the skills to apply that knowledge to financial decision } \\
\text { making and behaviours. } \\
\text { Efforts to improve financial literacy can take many forms. } \\
\text { These can include one-on-one counselling; curricula taught } \\
\text { in a classroom setting; workshops or information sessions; } \\
\text { print materials, such as brochures and pamphlets; and } \\
\text { mass media campaigns that can include advertisements } \\
\text { in magazines and newspapers or on television, radio, } \\
\text { or billboards. Many entities use the Internet to provide } \\
\text { financial education, which can include information and } \\
\text { training materials, practical tools such as budget worksheets } \\
\text { and loan and retirement calculators, and interactive financial } \\
\text { games }\end{array}$ \\
\hline Authors & Definition \\
\hline $\begin{array}{l}\text { A. Lusardi } \\
\text { and O. S. Mitchell }\end{array}$ & $\begin{array}{l}\text { Financial literacy is peoples' ability to process economic } \\
\text { information and make informed decisions about financial } \\
\text { planning, wealth accumulation, debt, and pensions. } \\
\text { Financial literacy has been defined as the level of financial } \\
\text { knowledge and the ability to apply the knowledge to improve } \\
\text { financial status (2014). } \\
\text { Financial literacy is the ability and tools needed to plan } \\
\text { and carry out retirement saving plans. Those who display } \\
\text { higher financial literacy are more likely to save and invest in } \\
\text { complex assets, such as stocks (2006) }\end{array}$ \\
\hline
\end{tabular}


Table 1 cnt'd

\begin{tabular}{l|l}
\hline \multicolumn{1}{c|}{ Authors } & \multicolumn{1}{c}{ Definition } \\
\hline W. G. Gale and R. Levine & $\begin{array}{l}\text { Financial literacy is the ability to make informed judgments } \\
\text { and effective decisions regarding the use and management } \\
\text { of money and wealth. Financially illiterate households } \\
\text { make poor choices that affect not only the decision-makers } \\
\text { themselves, but also their families and the public at large, } \\
\text { making the improvement of financial literacy a first-order } \\
\text { concern for public policy }\end{array}$ \\
\hline $\begin{array}{l}\text { Z. Kovalčíková, } \\
\text { L. Smoroň and R. Strenk }\end{array}$ & $\begin{array}{l}\text { Financial literacy is the indication of a state of constant } \\
\text { development that allows to each person to respond } \\
\text { effectively to new personal facts and a constantly changing } \\
\text { economic environment }\end{array}$ \\
\hline $\begin{array}{l}\text { B. D. Bernheim } \\
\text { and D. M. Garrett }\end{array}$ & $\begin{array}{l}\text { Financial literacy is an not isolated category but a specialised } \\
\text { part of economic literacy that is related to the ability to } \\
\text { ensure income, to move on the labour market, to make } \\
\text { decisions about one's payments, and the ability to realise the } \\
\text { possible consequences of the one's decisions on current and } \\
\text { future income }\end{array}$ \\
\hline J. Xiao & $\begin{array}{l}\text { Financial literacy has not yet been directly linked to how } \\
\text { households choose among different kinds of assets }\end{array}$ \\
\hline
\end{tabular}

Sources: Xiao (2016), OECD/INPE (2015), Gale and Levine (2010), GAO (2014), Lusardi and Mitchell (2006, 2014), Kovalčíková, Smoroň, and Strenk (2011), ACFL (2008), Bernheim and Garrett (2003).

\section{Measuring Financial Literacy}

The experiment consisted in investigating financial knowledge and awareness. Participants of the study were be divided into two groups. One of the groups was be trained in basic economic concepts, while the other one was the reference group. The training course lasted approximately 30 minutes and was conducted by a university lecturer. Two survey questionnaires were used for data collection: ex post and ex ante. The first study was conducted a week before the course. The second study was conducted a month after the course was complete. The questions were not exactly the same as in the first study, but the answers to those questions were fully comparable.

To measure financial literacy and investment attitudes we used a questionnaire developed by the Italian team (Brugiavini et al. 2015). The questionnaire included three questions to measure financial literacy: "Inflation", "Interest compounding" and "Diversification", and three 
questions to measure investment attitudes: "Real vs Nominal", "Investment plan", "Rule of 72". We asked one more question to assess how the participants rated their financial literacy. This additional question focused on measuring the respondents' self-assessed financial literacy according to a numerical scale from 1 to 7 , with 1 being the lowest and 7 the highest.

The experiment was carried out in Italy and in Poland (pilot version). In Italy it was conducted at a university in the north-east of the country. The experiment was conducted via the internet (among 579 persons) and in a laboratory (100 persons) in the 2013/2014 academic year. In Poland the pilot version of the experiment was conducted at the University of Szczecin in the north-east of the country. It was conducted using a paper questionnaire (among 185 persons) in the 2015/2016 academic year. The participants were students studying for Bachelor's degrees in management, logistics, law and administration.

\section{Evidence from the Experiment in Poland}

Table 2 presents the sample averages for all the outcomes of interest collected both before and after the intervention took place for the treated and control groups. Among the sample of participants who completed the experiment, 79 were assigned to the treated group and 89 to the control group. Unfortunately, the outcomes after intervention relate to a smaller sample (61 - treated group, and 74 - control group).

The probability of answering the two questions in the objective financial literacy domains ("Interest compounding" and "Diversification") correctly increases for students in the treated group but decreases for those in the control group. Unfortunately, the probability of answering the "inflation" question correctly decreases for students in the treated group and for those in the control group. The probability of answering the questions in the investment attitude domains correctly increases for students in the treated group and for those in the control group.

The greatest variation is in the "Real vs nominal" question. For this question the probability of choosing the correct answer increases by $48 \%$ for the treated group and by $24 \%$ for the control group. For the "Investment plan" question this probability increases by $24 \%$ for the treated group and decreases by $3 \%$ for the control group. For the "Rule of 72 " question this probability increases by $37 \%$ for the control group and decreases by $18 \%$ for the treated group. If we look at the variation in the overall number of correct answers in the investment attitudes domains, we find that it increased by 
about $16 \%$ for participants of the short financial course and by $24 \%$ for the control group.

Finally, it is worth noting that self-assessed financial literacy, which measures respondents' confidence in their financial education, increased by $10 \%$ for the treated group and by $11 \%$ for the control group.

Table 2. Financial Literacy, Investment Attitudes, and Self-assessed Financial Literacy before and after the Intervention for the Control and the Treated Group

\begin{tabular}{l|c|c|c|c}
\hline \multirow{2}{*}{ Specification } & Before intervention & \multicolumn{2}{c}{ After intervention } \\
\cline { 2 - 5 } & treated & control & treated & control \\
\hline \multicolumn{4}{c}{ Financial literacy $\%$ of correct answers) } \\
\hline Inflation & $62 \%$ & $67 \%$ & $49 \%$ & $47 \%$ \\
\hline Interest compounding & $42 \%$ & $49 \%$ & $43 \%$ & $35 \%$ \\
\hline Diversification & $63 \%$ & $74 \%$ & $66 \%$ & $43 \%$ \\
\hline Number of correct answers & 1.7 & 1.9 & 1.57 & 1.26 \\
\hline \multicolumn{5}{c}{ Investment attitudes $(\%$ of correct answers) } \\
\hline Real vs nominal & $45 \%$ & $50 \%$ & $67 \%$ & $64 \%$ \\
\hline Investment plan & $33 \%$ & $44 \%$ & $41 \%$ & $43 \%$ \\
\hline Rule of 72 & $52 \%$ & $40 \%$ & $43 \%$ & $55 \%$ \\
\hline Number of correct answers & 1.3 & 1.3 & 1.51 & 1.62 \\
\hline \multicolumn{5}{|c|}{ Self-assessed financial literacy } \\
\hline Mean score & 3.19 & 3.59 & 3.53 & 4.0 \\
\hline Observations & 79 & 89 & 61 & 74 \\
\hline
\end{tabular}

Source: based on the primary research.

Table 3. Correlation between Financial Literacy, Investment Attitudes, and Self-assessed Financial Literacy

\begin{tabular}{l|c|c}
\hline \multirow{2}{*}{\multicolumn{1}{c|}{ Specification }} & \multicolumn{2}{c}{ Self-assessed financial literacy } \\
\cline { 2 - 3 } & before intervention & after intervention \\
\hline Financial literacy & $0.1127(p=0.156)$ & $-0.012(p=0.893)$ \\
\hline Investment attitudes & $0.1127(p=0.100)$ & $0.0981(p=0.271)$ \\
\hline
\end{tabular}

Source: based on the primary research.

Table 3 shows the correlation between self-assessed literacy and financial literacy and investment attitudes. Unfortunately, all correlations are statistically insignificant $(p>0.050)$. The experiment in Poland was conducted on a pilot group, but reveals the restrictions that can prevent such an experiment from being conducted. 


\section{Financial Literacy in Poland and Italy}

For several years now, the world has been conducting research on financial literacy. Professor Elaine Kempson from the Personal Finance Research Centre in Bristol published a report (Kempson 2009) devoted to the methodology of financial literacy research, in which she draws attention to the problem of the worldwide variety of research in terms of research assumptions, construction of questionnaires, determination of the research sample, etc. The comparative analysis of the different financial literacy studies carried out in Poland and Italy is incorrect from a methodological point of view, hence the results and conclusions of international studies conducted both in Poland and Italy will be presented below.

In 2012, ING Group examined financial literacy in 11 European countries: Spain, France, Italy, Turkey, Austria, Germany, Netherlands, Belgium, Luxembourg, Poland and the UK. Poland took 7th place in the financial knowledge test with a score below the average for all countries (2.74 correct answers), while Italy took 2nd place (about 2.8 correct answers). The questions in the test were related to issues such as interest rates, inflation, bonds, mortgages, profit, and return.

For the first time in 2012, the OECD Programme for International Student Assessment (PISA) measured the financial literacy of 15-year-old students. The questions respondents were asked were aimed at identifying the level of financial knowledge and assessing the behaviours and attitudes of many aspects of financial awareness, such as managing household budgets, short- and long-term financial planning, and the determinants of the choice of financial products. Out of the 18 participating countries, 12 are in Europe, including Poland and Italy. The research was repeated in 2015. The second assessment covered 15 countries and economies, including Poland and Italy. The financial literacy assessment methodology is presented in the PISA 2015 Assessment and Analytical Framework (OECD 2016b). Poland's mean score in financial literacy performance was 510 in 2012 and decreased by 25 points to 485 in 2015, while Italy's mean score increased from 466 in 2012 to 483 in 2015 (OECD 2017, p. 179). The single continuous scale of financial literacy constructed for the PISA 2015 assessment was divided into five levels according to robust statistical principles. The descriptions of the proficiency levels were generated on the basis of the tasks assigned within each level in order to encapsulate the kinds of knowledge and skills needed to successfully complete those tasks. The set of descriptions is presented as a proficiency scale (OECD 2017, p. 75). Level 5 is the highest described 
level, and Level 1 is the lowest. The distribution of Polish and Italian student performance across the proficiency levels is shown in Table 4. More Polish than Italian students scored 624.63 points or above (Level 5). In 2015, the financial literacy assessment was also conducted among adults (OECD 2016a, p. 17). However, Italy did not participate in the research.

Table 4. Percentage of Polish and Italian Students at Each Proficiency Level in Financial Literacy

\begin{tabular}{l|c|c|c|c|c}
\hline \multirow{4}{*}{ Country } & \multicolumn{5}{|c}{ Percentage of students at each proficiency level in PISA 2015 } \\
\cline { 2 - 6 } & $\begin{array}{c}\text { Level 1 or } \\
\text { below (below } \\
400.33 \\
\text { points) }\end{array}$ & $\begin{array}{c}\text { Level 2 (from } \\
400.33 \text { to less } \\
\text { than 475.10 } \\
\text { points) }\end{array}$ & $\begin{array}{c}\text { Level 3 (from } \\
475.10 \text { to less } \\
\text { than 549.86 } \\
\text { points) }\end{array}$ & $\begin{array}{c}\text { Level 4 (from } \\
549.86 \text { to less } \\
\text { than 624.63 } \\
\text { points) }\end{array}$ & $\begin{array}{c}\text { Level 5 (at or } \\
\text { above 624.63 } \\
\text { points) }\end{array}$ \\
\hline Italy & 19.8 & 25.2 & 29.3 & 19.2 & 6.5 \\
\hline Poland & 20.1 & 24.5 & 28.4 & 19.0 & 8.0 \\
\hline
\end{tabular}

Source: OECD (2017, p. 179).

Standard \& Poor's Ratings Services, in collaboration with renowned research institutions including Gallup, the World Bank Development Research Group and the Global Financial Literacy Excellence Center, conducted a survey whose aim was to determine the level of global financial knowledge ${ }^{1}$. In the S\&P Global FinLit Survey, financial literacy was measured by four questions concerning basic numeracy, interest compounding, inflation, and risk diversification ${ }^{2}$. In the research, a person is defined as financially literate when he or she correctly answers at least three out of the four financial concepts described above. Based on this definition, $33 \%$ of adults worldwide are financially literate. Poland in the general assessment of Standard \& Poor's, which includes 148 countries, took 40th position with a score of $42 \%$. This is a result similar to the average for the so-called new European Union (41\%) - the group of countries which joined the Community in 2004 or later - but is significantly lower than the average for the European Union as a whole, which is 52\%. To compare: Italy has some of the lowest financial literacy rates in the south of Europe. There are $37 \%$ of adults who are financially literate (Klapper, Lusardi \& Oudheusden 2015, pp. 6-8, 23-25).

\footnotetext{
${ }^{1}$ The survey was based on interviews with more than 150,000 adults across 148 countries. Of the 148 countries targeted for data collection in 2014, 144 countries successfully collected data and met Gallup quality standards.

${ }^{2}$ The questions are available in Klapper, Lusardi, and van Oudheusden (2015).
} 
To compare the results of our experiment with the Italian one, the subjects in Italy were students at a medium-sized university in the north-east of the country. The research sample consisted of 579 students in the field experiment and 100 students in the laboratory experiment. Based on the sample, the Italian team provided field and laboratory evidence that a small-scale training intervention has both a statistically and economically significant effect on subjective and objective assessments of financial knowledge. Their research also shows that the intervention increases self-assessed knowledge more than actual financial knowledge (Brugiavini et al. 2015).

To conclude: both Poland and Italy have low levels of financial literacy, which is a good reason to seek effective ways of improving it. Unfortunately, the financial education experiment was exposed to a number of external factors that are difficult to measure and adversely affected the results of the study.

\section{Conclusions}

In summarising of the presented theoretical and empirical deliberations, one should point to the methodological limitations of the experiment, which significantly affected its results. These include:

- the respondents' lack of anonymity, which in many cases resulted in consent not being given to participate in the study,

- the respondents' lack of motivation to complete the questionnaires questions left unanswered or marked randomly,

- the control group was susceptible to the influence of other factors that also could lead to changes in behaviour and increase financial knowledge,

- the returns of end surveys were unfortunately at a lower level than those conducted before the experiment.

Statistical analysis of the obtained results allowed us to demonstrate that undergoing a course in finance raises subjective assessment of the level of financial literacy and objective assessment of investment attitudes. Unfortunately, it failed to demonstrate that undergoing a course in finance raises objective assessment of financial literacy, which is probably due to the methodological limitations of conducted pilot study.

\section{Bibliography}

ACFL (2008) "Annual report to the Advisory Council on Financial Literacy". Advisory Council on Financial Literacy. 
Ambuehl, S., Bernheim, B. and Lusardi, A. (2014) "A Method for Evaluating the Quality of Financial Decision Making, with an Application to Financial Education". NBER Working Paper No. 20618, National Bureau of Economic Research.

Bernheim, B. D. and Garrett, D. M. (2003) "The Effects of Financial Education in the Workplace: Evidence from a Survey of Households". Journal of Public Economics 87: 1487-1519, https://doi.org/10.1016/s0047-2727(01)00184-0.

Brown, A., Collins, M., Schmeiser, M. and Urban, C. (2014) State Mandated Financial Education and the Credit Behavior of Young Adults. The Federal Reserve System, Finance and Economics Discussion Series (2014-68). Washington DC: Federal Reserve Board, https://doi.org/10.2139/ssrn.2495884.

Brugiavini, A., Cavapozzi, D., Padula, M. and Pettinicchi Y. (2015) Financial Education, Literacy and Investment Attitudes. Netspar, DP-06/2015-014, https://doi.org/102139/ ssrn.2637878.

Delgadillo, L. M. (2014) "Financial Clarity: Education, Literacy, Capability, Counselling, Planning, and Coaching”. Family and Consumer Sciences Research Journal 43 (1), https://doi.org/10.1111/fcsr.12078.

Gale, W. G. and Levine, R. (2010) Financial Literacy: What Works? How Could It Be More Effective? Financial Literacy Research Consortium, October, https://doi.org/10.2139/ ssrn.1758910.

GAO (2014) Financial Literacy, Overview of Federal Activities, Programs, and Challenges. United States Government Accountability Office.

INFE (2011) Measuring Financial Literacy. Core Questionnaire in Measuring Financial Literacy: Questionnaire and Guidance Notes for Conducting an Internationally Comparable Survey of Financial Literacy. Paris: OECD.

Kempson, E. (2009) Framework for the Development of Financial Literacy Baseline Surveys: A First International Comparative Analysis. OECD.

Klapper, L., Lusardi, A. and van Oudheusden P. (2015) Financial Literacy around the World: Insights from Standard \& Poor's Ratings Services Global Financial Literacy Survey, p. 6: http://gflec.org/wp-content/uploads/2015/11/3313-Finlit_Report_FINAL5.11.16.pdf?x28148 (accessed: 11 June 2018).

Kovlačikova, Z., Smoroň, L. and Strenk, R. (2011) "Fundamentals of Financial Literacy" in K. Zvaríková and J. Majerová Financial Literacy in the Slovak Republic. Procedia Social and Behavioral Sciences, Vol. 110, 24 January 2014. Elsevier.

Lusardi, A. and Mitchell, O. (2006) Financial Literacy and Planning: Implications for Retirement Wellbeing. Report Retirement Research Consortium (RRC) and the Pension Research Council, Wharton School, October, NBER Working Paper A7078, https://doi.org/10.3386/w17078.

Lusardi, A. and Mitchell, O. S. (2014) "The Economic Importance of Financial Literacy: Theory and Evidence”. Journal of Economic Literature 52 (1), https://doi.org/10.1257/ jel.52.1.5.

NFEC (2014) Financial Literacy Solutions. National Financial Educators Council, http://www.financialeducatorscouncil.org/financial-literacy-definition.html (accessed: 11 June 2018).

OECD (2016a) Financial Education in Europe: Trends and Recent Developments. Paris: OECD Publishing, https://doi.org/10.1787/9789264254855-en. 
OECD (2016b) "PISA 2015 Financial Literacy Framework" in PISA 2015 Assessment and Analytical Framework: Science, Reading, Mathematics and Financial Literacy. Paris: OECD Publishing, https://doi.org/10.1787/9789264255425-en.

OECD (2017) PISA 2015 Results (Volume IV): Students' Financial Literacy. Paris: OECD Publishing, https://doi.org/10.1787/9789264270282-en.

OECD/INFE (2015) National Strategies for Financial Education. OECD/INFE Policy Handbook. Paris.

Xiao, J. (2016) Handbook of Consumer Finance Research. Second edition. Springer.

Xiao, J. and O’Neill B. (2016) "Consumer Financial Education and Financial Capability". International Journal of Consumer Studies 40 (6), https://doi.org/10.1111/ijcs.12285.

\section{Abstract}

\section{Poprawa wiedzy i umiejętności finansowych - wyniki eksperymentu}

Celem artykułu jest wykazanie, że krótki kurs z zakresu finansów pozytywnie wpływa na subiektywną i obiektywną ocenę poziomu wiedzy i umiejętności finansowych. Artykuł prezentuje wyniki pilotażowego eksperymentu dotyczącego wiedzy i umiejętności finansowych, który został przeprowadzony na Uniwersytecie Szczecińskim w 2016 r. Eksperyment jest efektem współpracy międzynarodowej, na podstawie metodyki badań zaproponowanej przez Włochów i dotyczy trzech zagadnień: obliczania odsetek, inflacji i dywersyfikacji ryzyka.

Na podstawie przeprowadzego eksperymentu można wnioskować, że kurs z zakresu finansów ma pozytywny wpływ na subiektywną ocenę poziomu wiedzy i umiejętności finansowych oraz obiektywną ocenę postaw inwestycyjnych.

Słowa kluczowe: wiedza finansowa, planowanie finansowe, edukacja finansowa, postawy inwestycyjne. 